\title{
Antibacterial Activity of Pharbitin, Isolated from the Seeds of Pharbitis nil, against Various Plant Pathogenic Bacteria ${ }^{\text {[ }}$
}

\author{
Hoa Thi Nguyen ${ }^{1}$, Nan Hee Yu ${ }^{1}$, Ae Ran Park ${ }^{1}$, Hae Woong Park ${ }^{2}$, In Seon Kim ${ }^{1}$, and Jin-Cheol Kim ${ }^{1 *}$ \\ ${ }^{1}$ Department of Agricultural Chemistry, Institute of Environmentally Friendly Agriculture, College of Agriculture and Life Sciences, \\ Chonnam National University, Gwangju 61186, Republic of Korea \\ ${ }^{2}$ RED Division, World Institute of Kimchi, Gwangju 61755, Republic of Korea
}

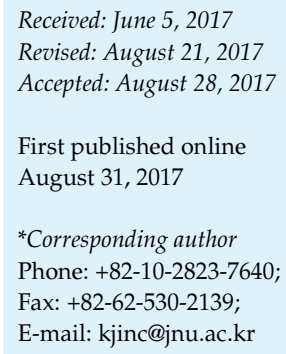

S upplementary data for this paper are available on-line only at http://jmb.or.kr.

pISSN 1017-7825, eISSN 1738-8872

\section{Copyright(C) 2017 by}

The Korean Society for Microbiology and Biotechnology

\begin{abstract}
This study aimed to isolate and characterize antibacterial metabolites from Pharbitis nil seeds and investigate their antibacterial activity against various plant pathogenic bacteria. The methanol extract of $P$. nil seeds showed the strongest activity against Xanthomonas arboricola pv. pruni (Xap) with a minimum inhibition concentration (MIC) value of $250 \mu \mathrm{g} / \mathrm{ml}$. Among the three solvent layers obtained from the methanol extract of $P$. nil seeds, only the butanol layer displayed the activity with an MIC value of $125 \mu \mathrm{g} / \mathrm{ml}$ against Xap. An antibacterial fraction was obtained from $P$. nil seeds by repeated column chromatography and identified as pharbitin, a crude resin glycoside, by instrumental analysis. The antibacterial activity of pharbitin was tested in vitro against 14 phytopathogenic bacteria, and it was found to inhibit Ralstonia solanacearum and four Xanthomonas species. The minimum inhibitory concentration values against the five bacteria were $125-500 \mu \mathrm{g} / \mathrm{ml}$ for the $\mathrm{n}$-butanol layer and $31.25-125 \mu \mathrm{g} / \mathrm{ml}$ for pharbitin. In a detached peach leaf assay, it effectively suppressed the development of bacterial leaf spot, with a control value of $87.5 \%$ at $500 \mu \mathrm{g} / \mathrm{ml}$. In addition, pharbitin strongly reduced the development of bacterial wilt on tomato seedlings by $97.4 \%$ at $250 \mu \mathrm{g} / \mathrm{ml}, 7$ days after inoculation. These findings suggest that the crude extract of $P$. nil seeds can be used as an alternative biopesticide for the control of plant diseases caused by $R$. solanacearum and Xanthomonas spp. This is the first report on the antibacterial activity of pharbitin against phytopathogenic bacteria.
\end{abstract}

Keywords: Antibacterial activity, Pharbitis nil seeds, pharbitin, bacterial leaf spot, tomato wilt

\section{Introduction}

Pathogenic bacteria are a major cause of disease in plants and reduce the yield of crops worldwide. Xanthomonas arboricola pv. pruni (Xap) is an important invasive phytopathogenic bacterium, with a broad host range including peach, nectarine, prune, plum, and apricot. Symptoms of this disease are fruit spots, leaf spots, and twig cankers [1]. According to Stefani [2], damage caused to plum orchards in northern Italy by Xap has been estimated at $11.200 €$ per ha (cv. Golden Plum) or 9,500 € per ha (cv. Angeleno). Yield losses of plums, peaches, and nectarines in Japan were up to $10,000 €$ per ha [2].

Ralstonia solanacearum (Rs) is a soil- and water-borne gram-negative phytopathogenic bacterium, and causes bacterial wilt diseases, affecting hundreds of species. Plants are infected through either the wounds or at the site of emergent root tips [3,4]. It causes bacterial wilt in over 200 plant species, including tomato, potato, pepper, peanut, tobacco, eggplant, and banana [5], and has a major impact on crop production all over the world. Control of bacterial wilt is difficult, and the most effective approach is to use crops resistant to the pathogen. The use of commercial antibiotics, copper compounds, and synthetic pesticides to control various plant pathogenic bacteria has improved the situation, but their long-term use has resulted in environmental pollution, residual toxicity, and the development of resistance in the target pathogens. Accordingly, 
there is a need for natural biopesticides based on plants and microbial-derived materials that can replace synthetic bactericides [6-9].

The largest genus of the morning glory family Convolvulaceae is Pharbitis (Ipomoea), with approximately 600 species [10, 11]. One of these, P. nil (I. nil), is widely distributed in Southeast Asia [12]. The chemical compositions of Pharbitis spp. have been investigated, and it was found to consist of resin glycosides, phenolic amides, gibberellins, flavonoids, and hevein-like proteins [13-17]. The seeds of $P$. nil have been used for a long time in the traditional medicines of Korea, China, and Japan as purgative drugs $[18,19]$. The major ingredients of the genus Pharbitis are well known as "resin glycosides," including pharbitin and convolvulin [20]. The substances derived from the seeds of P. nil were reported to exhibit antitumor [12, 21, 22], antifungal [16, 23, 24], anticancer [25], and anthelmintic [26] activities, but no information regarding their antibacterial activity against plant pathogenic bacteria has been disclosed.

In order to discover new antibacterial active substances, 225 medicinal plant extracts were tested in vitro for antibacterial activity against two plant pathogenic bacteria. The methanol extract of Pharbitis nil seeds showed the strongest activity against Rs and Xap. Therefore, this study aimed to isolate and characterize the antibacterial metabolites contained in this extract, and to examine their in vitro antibacterial activity against various plant pathogenic bacteria. Additionally, their disease control efficacy was evaluated against bacterial leaf spots on peach leaves in a detached leaf bioassay, and bacterial wilt on tomato seedlings.

\section{Materials and Methods}

\section{Bacterial Strains and Culture Conditions}

The following 14 phytopathogenic bacterial strains were used: Acidovorax avenae subsp. cattleyae (Aac; bacterial brown spot of Phalaenopsis), Acidovorax konjaci (Ak; bacterial blight of konjac), Agrobacterium tumefaciens (At; crown gall of apple), Burkholderia glumae (Bg; bacterial panicle blight of rice), Clavibacter michiganensis subsp. michiganensis ( $\mathrm{Cmm}$; bacterial wilt and canker of tomato), Pectobacterium carotovorum subsp. carotovorum (Pcc; bacterial soft rot of potato), Pectobacterium chrysanthemi (Pc; bacterial soft rot of aloe), Pseudomonas syringae pv. actinidiae (Psa; bacterial canker of kiwifruit), Pseudomonas syringae pv. lachrymans (Psl; angular leaf spot of cucumber), Ralstonia solanacearum (Rs; bacterial wilt of tomato), Xanthomonas arboricola pv. pruni (Xap; bacterial leaf spot of peach), Xanthomonas axonopodis pv. citri (Xac; citrus canker), Xanthomonas euvesicatoria (Xe; bacterial spot of tomato), and Xanthomonas oryzae pv. oryzae (Xoo; bacterial leaf blight of rice). Rs and Psa were isolated by Prof. S.-W. Lee of Dong-A University
[27] and Prof. Y. J. Koh of Sunchon National University [28], respectively, who kindly supplied us with samples, which were preserved at $-80^{\circ} \mathrm{C}$ at Chonnam National University. All other bacterial strains were acquired from the Korean Agricultural Culture Collection (KACC), National Academy of Agricultural Sciences. All strains were grown on tryptic soy broth (TSB) and tryptic soy agar (TSA) (Becton, Dickinson and Co., USA) and incubated at $30^{\circ} \mathrm{C}$, expect for Psa, which was incubated at $25^{\circ} \mathrm{C}$, and Xanthomonas spp., which was incubated at $28^{\circ} \mathrm{C}$.

\section{Chemicals}

Streptomycin sulfate was purchased from Sigma-Aldrich Co. (USA). Tween-20 and all the chemicals and solvents used, including methanol $(\mathrm{MeOH})$, ethyl acetate (EtOAc), n-butanol $(\mathrm{BuOH})$, chloroform $\left(\mathrm{CHCl}_{3}\right)$, acetone, potassium carbonate $\left(\mathrm{K}_{2} \mathrm{CO}_{3}\right)$, hydrochloric acid $(\mathrm{HCl})$, and sodium sulfate $\left(\mathrm{Na}_{2} \mathrm{SO}_{4}\right)$, were of analytical grade and acquired from either E. Merck (Germany) or Daejung Chemicals (Korea).

\section{Plant Material}

The $\mathrm{MeOH}$ extract of $P$. nil seeds used in the antibacterial activity screening was acquired from the Korean Plant Extract Bank (Korea). The seeds of $P$. nil used for isolation of the active compounds were purchased from a Korean herbal medicine shop.

\section{Isolation of Antibacterial Substances}

The seeds of $P$. nil $(150 \mathrm{~g})$ were ground and extracted twice with $\mathrm{MeOH}(2 \times 2 \mathrm{~L})$ at room temperature. The extracts were filtered through a Whatman No. 2 filter paper and the filtrate was concentrated in vacuo to afford a brown syrup $(8 \mathrm{~g})$. This syrup was then suspended in distilled water $(500 \mathrm{ml})$ and then successively extracted with equal volumes of EtOAc and $\mathrm{BuOH}$ ( $\times 2$ for each). The organic layers and aqueous layer were concentrated in vacuo. The in vitro antibacterial activity of each layer was tested against Xap, and the $\mathrm{BuOH}$ layer was found to exhibit the strongest antibacterial activity. Accordingly, isolation of the bioactive compounds from the $\mathrm{BuOH}$ layer was pursued.

The $\mathrm{BuOH}$ layer ( $3.2 \mathrm{~g}$ ) was subjected to column chromatography on-silica gel column $(3.5-\mathrm{cm}$ inner diameter and $60-\mathrm{cm}$ length, Kiesel gel 60, 150 g, 70-230 mesh; E. Merck) by successive elution with $\mathrm{CHCl}_{3} / \mathrm{MeOH} /$ water / acetic acid (14/6/1/0.1 (v/v/v/v), $800 \mathrm{ml}$ ), to give seven fractions, F1-F7. Each fraction was analyzed using thin-layer chromatography (TLC) (Kiesel gel 60GF 254, 0.25-mm layer thickness; E. Merck) with the developing solvent $\mathrm{CHCl}_{3} / \mathrm{MeOH} /$ water $(6 / 4 / 1(\mathrm{v} / \mathrm{v} / \mathrm{v}))$. The fractions were individually assayed in vitro for growth inhibition of Xap. F1 was not found to inhibit growth. Fractions F2-F5 all inhibited growth to some extent. TLC of each showed a similar pattern of primary components when visualized under ultraviolet light (254 and $365 \mathrm{~nm}$ ). Visualization with $p$-anisaldehyde reagent showed one major component with an $R_{f}$ value of 0.8 . The F2-F5 fractions (1.47 g) were combined, concentrated, and subjected to Sephadex LH 20 column chromatography $(3 \mathrm{~cm}$ inner diameter, $80 \mathrm{~cm}$ 
length, $100 \mathrm{~g}$, bead size 18-111 $\mu \mathrm{m}$; GE Healthcare, Sweden), eluting with $100 \% \mathrm{MeOH}$. Four fractions (F21-F24) were obtained. In a TLC analysis using the solvent systems $\mathrm{CHCl}_{3} / \mathrm{MeOH} /$ water / acetic acid $(30 / 9 / 1 / 0.1(\mathrm{v} / \mathrm{v} / \mathrm{v} / \mathrm{v})), \mathrm{CHCl}_{3} / \mathrm{MeOH} /$ water / acetic acid $(12 / 8 / 1 / 0.1(\mathrm{v} / \mathrm{v} / \mathrm{v} / \mathrm{v}))$, and $\mathrm{CHCl}_{3} / \mathrm{MeOH} /$ water / acetic acid $(6 / 4 / 1 / 0.1(\mathrm{v} / \mathrm{v} / \mathrm{v} / \mathrm{v}))$, the active fraction of $\mathrm{F} 21$ appeared as a single spot when sprayed with $p$-anisaldehyde and charred. F21 was obtained as a pale yellow power.

\section{Alkaline Hydrolysis of F21}

The ${ }^{1} \mathrm{H}$ NMR spectrum of F21 showed the presence of olefinic, sugar, and saturated hydrocarbon protons. The spectrum was similar to that of pharbitin, a mixture of seven oligoglycosides of hydroxyl fatty acid [29]. In order to get more information by chemical degradation, F21 was hydrolyzed using alkaline. F21 (470 mg) was suspended in $1 \%$ aqueous $\mathrm{K}_{2} \mathrm{CO}_{3}(10 \mathrm{ml})$ and heated at $90^{\circ} \mathrm{C}$ for $2.5 \mathrm{~h}$. The mixture was adjusted to $\mathrm{pH} 4$ with $1 \mathrm{~N} \mathrm{HCl}$ and extracted with EtOAc $(10 \mathrm{ml})$. The organic phase was washed with $\mathrm{H}_{2} \mathrm{O}$ and dried over $\mathrm{Na}_{2} \mathrm{SO}_{4}$ [30]. The aqueous layer was concentrated at $60^{\circ} \mathrm{C}$ and then chromatographed on a Sephadex LH-20 column (3.5-cm inner diameter and 60-cm length, $100 \mathrm{~g}$, bead size 18-111 $\mu \mathrm{m}$; GE Healthcare), eluting with $100 \% \mathrm{MeOH}$. Four fractions (F21W1-F21W4) were obtained. The fractions were monitored using TLC with the developing solvent $\mathrm{CHCl}_{3}$ / $\mathrm{MeOH} /$ water $(6 / 4 / 1(\mathrm{v} / \mathrm{v} / \mathrm{v}))$. The residue of $\mathrm{F} 21 \mathrm{~W} 4$ was separated by preparative TLC using a mixture of $\mathrm{CHCl}_{3} / \mathrm{MeOH} /$ water/acetic acid $(55 / 36 / 8 / 1(\mathrm{v} / \mathrm{v} / \mathrm{v} / \mathrm{v}))$ to yield $85.3 \mathrm{mg}$ of a pure compound, called compound 1 .

\section{Structure Determination of the Antibacterial Substance}

The chemical structure of compound 1 was determined by nuclear magnetic resonance (NMR) spectroscopy and highresolution electrospray ionization mass spectrometry (HR-ESI-MS) analyses. ${ }^{1} \mathrm{H}-\mathrm{NMR}$ spectra were measured in pyridine $\mathrm{d}_{5}$ (Cambridge Isotope Laboratories, Inc., USA) with a Bruker Avance III HD $500 \mathrm{MHz}$ instrument (Bruker Biospin GmbH, Germany) at $500 \mathrm{MHz}$. Chemical shifts were measured using tetramethylsilane as the internal standard. HR-ESI-MS was determined by a Synapt G2 HDMS quadrupole time-of-flight (QTOF) mass spectrometer equipped with an electrospray ion source (Waters, UK). Coupling constants are reported in Hertz unit. The chemical structure of compound 1 was analyzed on the basis of ${ }^{1} \mathrm{H}$-NMR spectral data and HR-ESI-MS

\section{In Vitro Antibacterial Activity}

In vitro antibacterial activity was determined in 96-well microtiter plates using the broth microdilution method [6]. The EtOAc, $\mathrm{BuOH}$, and aqueous layers were dissolved in acetone, $\mathrm{MeOH}$, and distilled water, respectively, at a concentration of $500 \mathrm{mg} / \mathrm{ml}$. The fractions obtained during the isolation of the active compound, F21 and compound 1, were dissolved in $\mathrm{MeOH}$ at a concentration of $500 \mathrm{mg} / \mathrm{ml}$. The bioassays were conducted using 96-well plates, each well containing $100 \mu \mathrm{l}$ of TSB medium inoculated with pathogenic bacteria at $1 \times 10^{5} \mathrm{CFU} / \mathrm{ml}$, except for Xanthomonas spp. which was inoculated at $1 \times 10^{6} \mathrm{CFU} / \mathrm{ml}$. The final concentrations of the samples of F21 and compound 1 ranged from 7.8 to $500 \mu \mathrm{g} / \mathrm{ml}$. The final concentration of $\mathrm{MeOH}$ was less than $1 \%(\mathrm{v} / \mathrm{v})$, and the negative controls were treated with $1 \%$ $\mathrm{MeOH}$. Streptomycin sulfate was used as a positive control. It was dissolved in distilled water at a concentration of $10 \mathrm{mg} / \mathrm{ml}$ and the final concentrations of the treated streptomycin sulfate ranged from 1.56 to $100 \mu \mathrm{g} / \mathrm{ml}$. The blank wells were prepared with culture medium containing each extract at the same test concentration. All samples were incubated for $24-72 \mathrm{~h}$ at $30^{\circ} \mathrm{C}$, except for Xanthomonas spp., which was incubated at $28^{\circ} \mathrm{C}$, and Psa, which was incubated at $25^{\circ} \mathrm{C}$. Bacterial growth was measured using a microplate reader (Benchmark Plus; Bio-Rad, USA) at $600 \mathrm{~nm}$ $\left(\mathrm{OD}_{600}\right)$. The minimum inhibitory concentration $(\mathrm{MIC})$ was defined as the lowest concentration that completely inhibited bacterial growth. The assay was repeated three times in triplicate for each sample, against the individual bacterial species at all test concentrations.

\section{Disease Control Efficacy against Peach Bacterial Leaf Spot}

To evaluate the disease control efficacy of the $\mathrm{BuOH}$ layer and F21 against bacterial leaf spot caused by Xap, a detached leaf assay was conducted using leaves of peach trees [31]. Young apical leaves (6-9 cm long) were collected from the top of branches and transferred to a moist plastic chamber. The leaves were rinsed with sterile distilled water three times and dried using sterilized paper towels. The $\mathrm{BuOH}$ layer and F21 were dissolved in $\mathrm{MeOH}$ at concentrations of $12.5,25$, and $50 \mathrm{mg} / \mathrm{ml}$. Each stock solution was diluted 100 -fold in distilled water containing $250 \mu \mathrm{g} / \mathrm{ml}$ Tween-20 to obtain concentrations of 125,250 , and $500 \mu \mathrm{g} / \mathrm{ml}$, respectively. Leaves treated with $1 \% \mathrm{MeOH}$ in Tween-20 $(250 \mu \mathrm{g} / \mathrm{ml})$ served as negative controls. Streptomycin sulfate at a concentration of $200 \mu \mathrm{g} / \mathrm{ml}$ in Tween-20 $(250 \mu \mathrm{g} / \mathrm{ml})$ was used as a positive control.

Xap was cultured on a TSB test tube at $28^{\circ} \mathrm{C}$ for $36-48 \mathrm{~h}$. Bacterial suspensions were adjusted in sterile distilled water to obtain an $\mathrm{OD}_{600}$ of 0.1 (approximately $1 \times 10^{8} \mathrm{CFU} / \mathrm{ml}$ ). Two leaves were dipped for $10 \mathrm{sec}$ in each chemical solution and then placed on a plastic dish at room temperature. After $4 \mathrm{~h}$, six wounds were made in each leaf using a forceps clamp, and then Xap $\left(10^{8} \mathrm{CFU} / \mathrm{ml}\right)$ was inoculated by dipping in the pathogen suspension. The two inoculated leaves were placed on $0.5 \%$ water agar in a petri dish (diameter $90 \mathrm{~mm}$, height $15 \mathrm{~mm}$ ) (20 ml per dish). The petri dishes were maintained at $28^{\circ} \mathrm{C}$ for $16 \mathrm{~h}$ in the light, and $8 \mathrm{~h}$ in the dark. Bacteria spot symptom development was recorded daily until day 5 post inoculation. Each experiment was repeated twice with two petri dishes per treatment. The disease incidence and control value were calculated using the following formulae:

$\%$ Disease incidence (DI) $=100 \times$ [number of bacterial leaf spots / number of all wounds]

$\%$ Control value $=100-[100 \times \%$ DI of treatment $/ \%$ DI of control $]$ 


\section{Disease Control Efficacy against Tomato Bacterial Wilt}

The disease control efficacy of the $\mathrm{BuOH}$ layer of P. nil and F21 against tomato bacterial wilt caused by Rs was evaluated in a growth room. The tomato seeds ("Seokwang"; FarmHannong Co., Korea) were grown in the greenhouse in vinyl pots filled with commercial horticulture nursery soil manufactured by the Punong Co. (Korea). Four-week-old tomato plants at the 4-5 true-leaf stage were transplanted into vinyl pots with a diameter of $7 \mathrm{~cm}$ (one plant per pot). Samples of the $\mathrm{BuOH}$ layer and F21 were dissolved in $\mathrm{MeOH}$ at concentrations of 50, 100, and $200 \mathrm{mg}$, and $12.5,25$, and $50 \mathrm{mg}$, respectively. The chemical solutions were then diluted with distilled water containing $250 \mu \mathrm{g} / \mathrm{ml}$ Tween-20 to obtain test concentrations of $500,1,000$, and $2,000 \mu \mathrm{g} / \mathrm{ml}$ for the $\mathrm{BuOH}$ layer, and 125, 250, and $500 \mu \mathrm{g} / \mathrm{ml}$ for F21. Rs was cultured on TSA at $30^{\circ} \mathrm{C}$ for $48 \mathrm{~h}$ and then the cells were harvested with sterile distilled water. The inoculum suspension was adjusted to $1 \times 10^{8} \mathrm{CFU} / \mathrm{ml}$.

Each chemical solution $(20 \mathrm{ml})$ was evenly applied to each pot by soil drench. After $6 \mathrm{~h}$, Rs was inoculated by applying $20 \mathrm{ml}$ of the inoculum suspension into the soil. Potted plants treated with Tween-20 solution containing $1 \% \mathrm{MeOH}$ served as controls, and streptomycin sulfate $(200 \mu \mathrm{g} / \mathrm{ml})$ was used as the bactericide control. The plants were maintained in a controlled climate at $30 \pm 2{ }^{\circ} \mathrm{C}$ with a relative humidity of $70-80 \%$. The pots were arranged as a randomized complete block with five replicates per treatment. The experiment was repeated three times.

The disease severity (DS) was recorded on a scale of $0-5$ as described by Winstead and Kelman [32]. The following scales were used: $0=$ no symptoms, $1=$ one leaf partially wilted, $2=$ one to two leaves wilted, $3=$ two to three leaves wilted, $4=$ four or more leaves wilted, and $5=$ death of the entire plant. The control value was calculated using the following formula:

$\%$ Control value $=100 \times$ [DS of control - DS of treatment $/$ DS of control]

\section{Statistical Analysis}

The data obtained in this study were evaluated by ANOVA, and statistical analysis of the significance of mean differences was performed using Duncan's HSD test for multiple comparisons $(p \leq 0.05)$ with the SAS software (ver. 9.3; SAS Institute, USA).

\section{Results}

\section{In Vitro Antibacterial Activity of Crude Extracts of $P$. nil} Seeds

The $\mathrm{MeOH}$ extract of $P$. nil seeds showed in vitro antibacterial activity against Xap with MIC values of $250 \mu \mathrm{g} / \mathrm{ml}$ (Fig. 1). The in vitro antibacterial activity of the two organic layers and one aqueous layer obtained from the $\mathrm{MeOH}$ extract were also evaluated. Of the three layers, the $\mathrm{BuOH}$ layer showed the strongest antibacterial activity against Xap with an MIC value of $250 \mu \mathrm{g} / \mathrm{ml}$ (Fig. 1). The

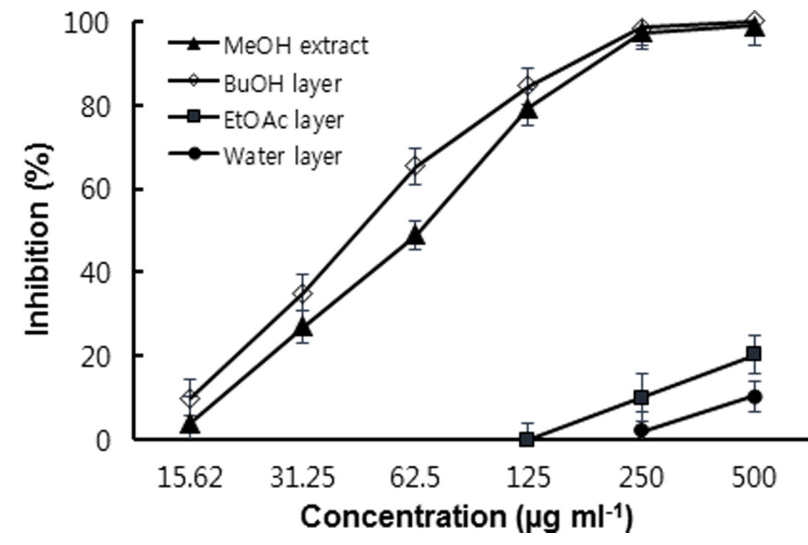

Fig. 1. Antibacterial activity of the methanol extract and three layers of Pharbitis nil seeds against Xanthomonas aboricola pv. pruni.

Each value represents the mean \pm standard deviation of three runs with two replicates per run $(\mathrm{MeOH}$ : methanol; $\mathrm{BuOH}$ : butanol; EtOAc: ethyl acetate).

other two layers were virtually inactive.

\section{Characterization of the Antibacterial Metabolite}

F21 was isolated from the $\mathrm{BuOH}$ layer of the $P$. nil seed extract, and appeared as a single spot on TLC (Fig. S1). However, the ${ }^{1} \mathrm{H}-\mathrm{NMR}$ spectrum of F21 clearly indicated it to be a mixture of resin glycosides (data not shown). F21 was hypothesized to be pharitin, a known mixture of seven oligoglycosides of hydroxyl fatty acid (Fig. 2) [29]. To confirm the identity of F21, it was hydrolyzed using $1 \%$ aqueous $\mathrm{K}_{2} \mathrm{CO}_{3}$. One major compound (compound 1) was purified from the alkaline hydrolysis products by Sephadex LH-20 and prep-TLC chromatographic methods as a white powder. The HR-ESI-MS results of compound 1 displayed ion peaks $[\mathrm{M}+\mathrm{Na}]^{+}$at $m / z \quad 1,045.4694$ and $[\mathrm{M}-\mathrm{H}]^{-}$at $m / z$ $1,021.4698$ in positive and negative modes, respectively, suggesting a molecular formula of $\mathrm{C}_{44} \mathrm{H}_{78} \mathrm{O}_{26}$ with six degrees of unsaturation (Fig. S2). The ${ }^{1} \mathrm{H}-\mathrm{NMR}$ spectrum of compound 1 exhibited signals corresponding to five anomeric protons $(\delta 6.26,5.89,5.40,5.21$, and 4.87$)$, three secondary methyls, perhaps corresponding to 6-deoxyhexose $(\delta 1.86,1.63$, and 1.52), a nonequivalent 2-methylene $(\delta 2.72$ and 2.87$)$, and a primary methyl $(\delta 0.95)$ ascribable to an ipurolic acid moiety (Table S1). Both ${ }^{1} \mathrm{H}-\mathrm{NMR}$ and HR-ESIMS data were identical to those of pharbitic acid $C$ reported by Ono et al. [30]. Thus, compound 1 was identified as pharbitic acid C (Fig. 2), and F21 as pharbitin.

\section{In Vitro Antibacterial Activity}

The in vitro antibacterial activity of the $\mathrm{BuOH}$ layer and 


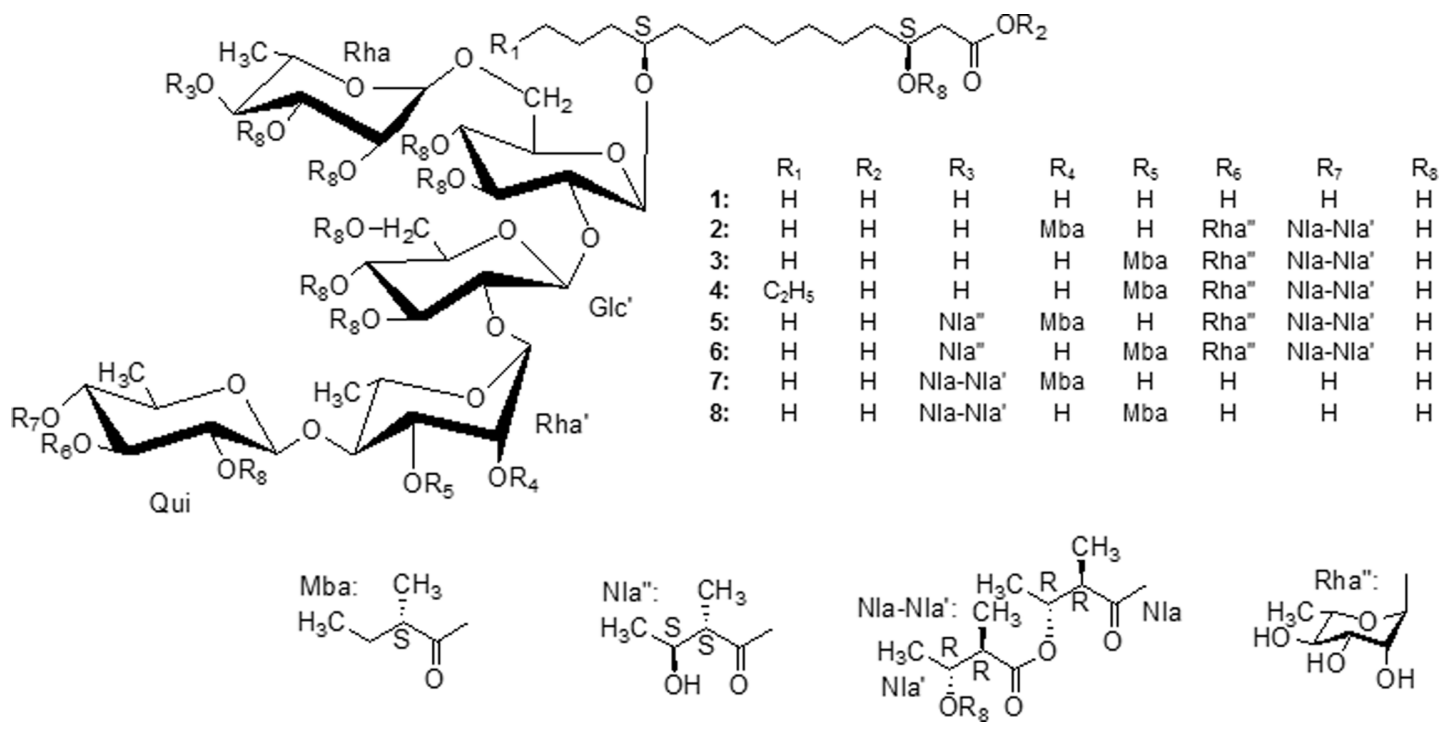

Fig. 2. Chemical structures of pharbitin (mixture of compounds 2-8) (Ono et al. [30]) and pharbitic acid C (compound 1).

F21 (pharbitin) was tested against 14 plant pathogenic bacteria (Table 1). The two samples exhibited specific in vitro antibacterial activity against Rs and Xanthomonas spp. $\mathrm{BuOH}$ and F21 displayed MIC values with a range of 125$500 \mu \mathrm{g} / \mathrm{ml}$ and $31.25-125 \mu \mathrm{g} / \mathrm{ml}$ against the five sensitive bacteria, respectively. Of the 14 bacteria, Rs and Xoo were most sensitive to pharbitin, with an MIC value of $31.25 \mu \mathrm{g} / \mathrm{ml}$, followed by Xap and Xe, which had MIC values of $125 \mu \mathrm{g} / \mathrm{ml}$ for the $\mathrm{BuOH}$ layer and $62.5 \mu \mathrm{g} / \mathrm{ml}$ for F21. Neither the $\mathrm{BuOH}$ nor the F21 layers were active against the other bacteria. In contrast, compound $\mathbf{1}$ did not show any activity against any of the 14 phytopathogenic bacteria tested, even at $500 \mu \mathrm{g} / \mathrm{ml}$.

\section{Disease Control Efficacy against Peach Bacterial Leaf Spot}

In a detached leaf bioassay, both the $\mathrm{BuOH}$ layer and F21 reduced the development of bacterial leaf spot on peach leaves in a dose-dependent manner. F21, at concentrations of 125,250 , and $500 \mu \mathrm{g} / \mathrm{ml}$, suppressed the development of bacterial leaf spot by $50 \%, 70.8 \%$, and $87.5 \%$, respectively. The control values of the $\mathrm{BuOH}$ layer against peach bacterial leaf spot were $29.2 \%, 54.2 \%$, and $75.0 \%$ at concentrations of 125,250 , and $500 \mu \mathrm{g} / \mathrm{ml}$, respectively. Streptomycin sulfate, used as the positive control, showed a control value of $91.7 \%$ at a concentration of $200 \mu \mathrm{g} / \mathrm{ml}$ (Fig. 3).

\section{Disease Control Efficacy against Tomato Bacterial Wilt}

The $\mathrm{BuOH}$ layer and F21 were evaluated for in vivo antibacterial activity against Rs on 4-week-old tomato seedlings. F21 significantly reduced the disease severity compared with untreated control plants sprayed with water in a dose-dependent manner (Fig. 4). Its disease control efficacy was comparable to or stronger than streptomycin sulfate. At 7 days after inoculation, the control values of pharbitin were $79.5 \%, 97.4 \%$, and $100 \%$ at 125,250 , and $500 \mu \mathrm{g} / \mathrm{ml}$, respectively. In comparison, the control value of streptomycin sulfate at $200 \mu \mathrm{g} / \mathrm{ml}$ was $76.9 \%$. The disease control efficacy of pharbitin was decreased 14 days after inoculation. The $\mathrm{BuOH}$ layer also strongly reduced the disease; its control values were $76.9 \%, 100 \%$, and $100 \%$ at $500,1,000$, and $2,000 \mu \mathrm{g} / \mathrm{ml}$, respectively, at 7 days after inoculation. However, the $\mathrm{BuOH}$ layer at $2,000 \mu \mathrm{g} / \mathrm{ml}$ caused phytotoxic symptoms of yellow chlorosis lesions on the leaves at 2 days after treatment.

\section{Discussion}

This study focused on the identification of an antibacterial principle in the $\mathrm{MeOH}$ extract of $P$. nil seeds, and the evaluation of its in vitro and in vivo activities against phytopathogenic bacteria. The hevein-like proteins from $P$. nil significantly suppressed plant pathogenic fungi, including Phytophthora capsici and Fusarium oxysporum in tomato (Solanum lycopersicum) [16]. Koo et al. [23] also reported antifungal activity of two hevein homologs isolated from the seeds of $P$. nil against Botrytis cinerea and Phytophthora parasitica. Anticancer activity of P. nil seed extracts and metabolites therefrom was observed against human tumor cell lines (A549, SK-OV-3, SK-MEL-2, and HCT-15) $[12,21,22]$. Treatment of the crude extract of $P$. nil 
Table 1. Minimum inhibitory concentration (MIC) values of the butanol layer and pharbitin against plant pathogenic bacteria.

\begin{tabular}{lccc}
\hline \multicolumn{1}{c}{ Pathogen } & \multicolumn{2}{c}{ MIC $(\mu \mathrm{g} / \mathrm{ml})$} \\
\cline { 2 - 4 } Acidovorax avenae subsp. cattlyae & Butanol layer & Pharbitin & Streptomycin sulfate \\
Agrobacterium konjaci & - & - & $>100$ \\
Agrobacterium tumefaciens & - & - & 6.25 \\
Burkholderia glumae & - & - & $>100$ \\
Clavibacter michiganensis subsp. michiganensis & - & - & 25 \\
Pectobacterium carotovorum subsp. carotovorum & - & - & 6.25 \\
Pectobacterium chrysanthemi & - & - & $>100$ \\
Pseudomonas syringae pv. actinidae & - & - & 12.5 \\
Pseudomonas syringae pv. lachrymans & - & - & 12.5 \\
Ralstonia solanacearum & - & 31.25 & 6.25 \\
Xanthomonas arboricola pv. pruni & 125 & 62.5 & 12.5 \\
Xanthomonas axonopodis pv. citri & 125 & 125 & 50 \\
Xanthomonas euvesicatoria & 500 & 62.5 & 12.5 \\
Xanthomonas oryzae pv. oryzae & 125 & 31.25 & 6.25 \\
\hline
\end{tabular}

$-:$ No activity.

A

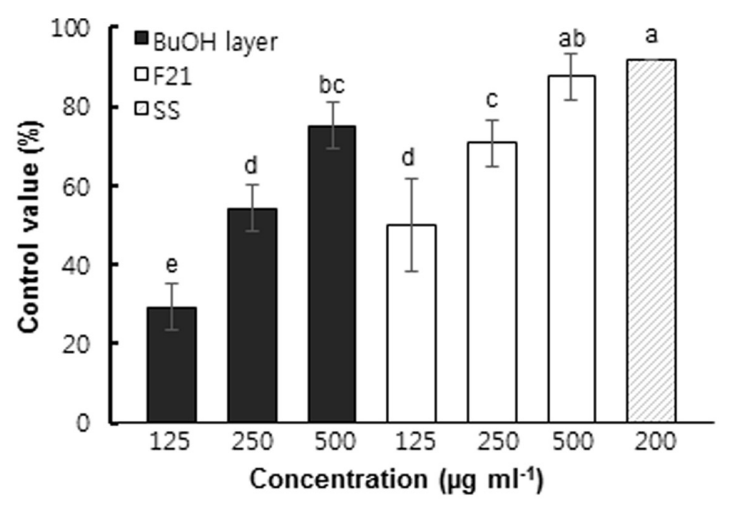

B

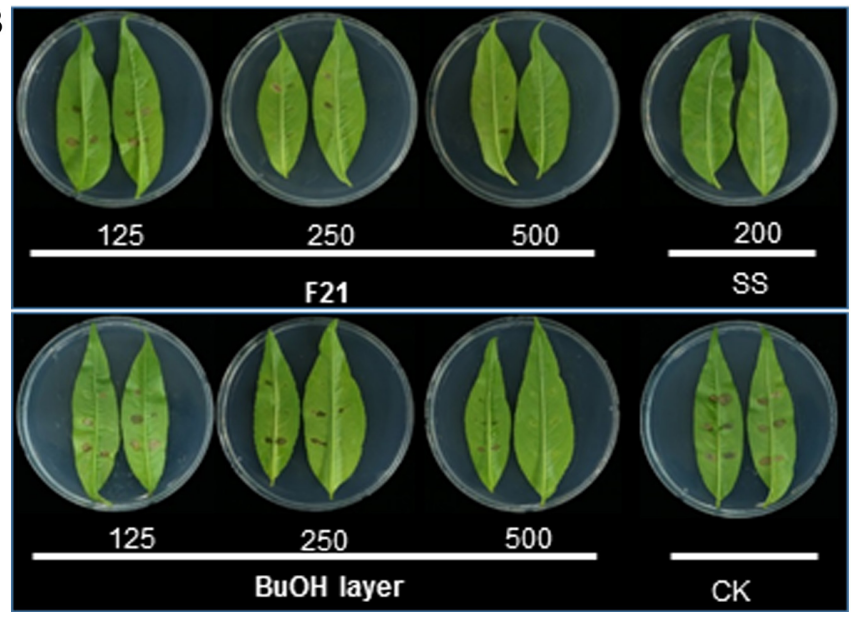

Fig. 3. Disease control efficacy of the BuOH layer and F21 (pharbitin) obtained from Pharbitis nil seeds against bacterial leaf spot caused by Xanthomonas arboricola pv. pruni on detached peach leaves.

(A) Mean percentage disease control value of the $\mathrm{BuOH}$ layer and F21 against bacterial leaf spot on a peach tree leaf after 5 days. Each value represents the mean \pm standard deviation of two runs with three replicates per run. Lowercase letters indicate that values are not significantly different from other values with the same letter according to Duncan's HSD test for multiple comparisons $(p \leq 0.05)$ with the SAS software (ver. 9.3; SAS Institute, USA). (B) Symptoms of bacterial leaf spot on detached peach leaves at 5 days after inoculation. BuOH: butanol layer; SS: streptomycin sulfate; CK: untreated control; unit: $\mu \mathrm{g} / \mathrm{ml}$.

induced growth inhibition and apoptosis of an AGS gastric cancer cell line [25].

Antibacterial activity of the other species of the Pharbitis genus has been reported against animal and human pathogenic bacteria. Pharbitis bahiensis-derived resin glycosides showed antibacterial activity against several bacteria, including Bacillus subtilis and Staphylococcus aureus [33]. The resin glycoside fractions isolated from Pharbitis stans exhibited antibacterial activity against $S$. aureus and B. sublitis [34]. Tricolorin A isolated from Pharbitis tricolor displayed 
A

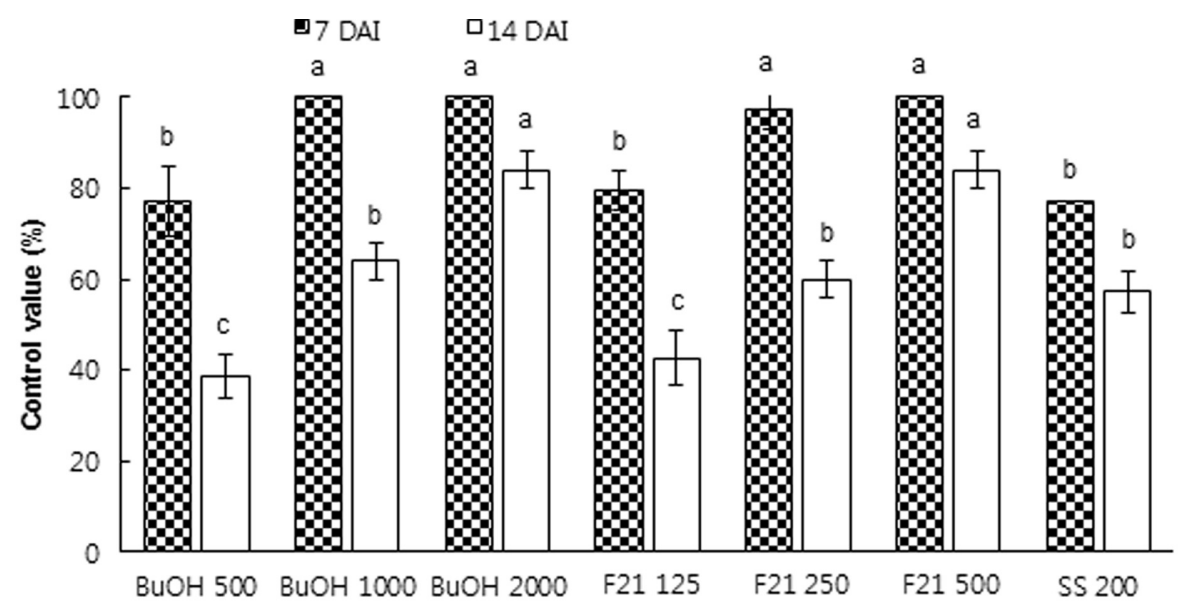

B

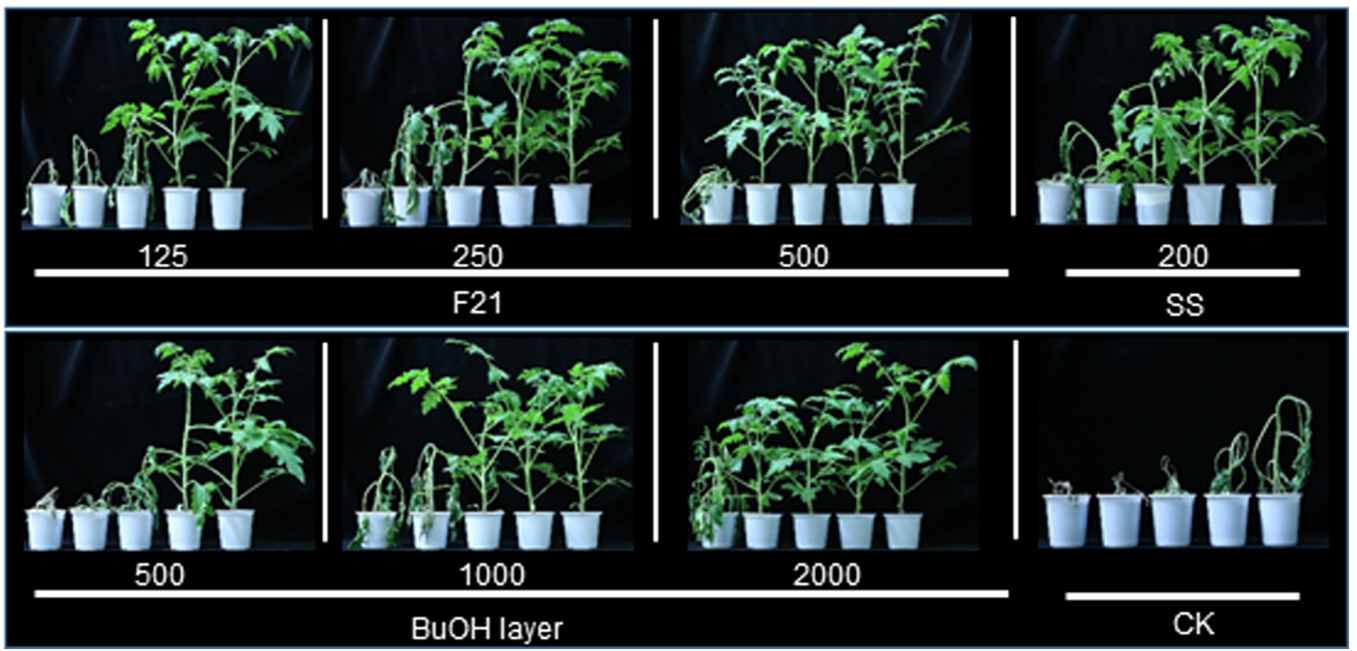

Fig. 4. Control efficacy of the BuOH layer and F21 (pharbitin) obtained from Pharbitis nil seeds in reducing wilting disease severity caused by Ralstonia solanacearum on tomato seedlings.

(A) Mean percentage disease control values of the $\mathrm{BuOH}$ layer and F21 against bacterial wilt on tomato seedlings at 7 and 14 days after inoculation. Each value represents the mean \pm standard deviation of two runs with three replicates per run. Lowercase letters indicate that values are not significantly different from other values with the same letter according to Duncan's HSD test for multiple comparisons $(p \leq 0.05)$ with the SAS software (ver. 9.3; SAS Institute, USA). (B) Symptoms of bacterial wilt on tomato seedlings at 14 days after inoculation. DAI: days after inoculation; BuOH: butanol layer; SS: streptomycin sulfate; CK: untreated control; unit: $\mu \mathrm{g} / \mathrm{ml}$.

strong antibacterial activity against $S$. aureus with an MIC value of $1.8 \mu \mathrm{g} / \mathrm{ml}$, and significant cytotoxic activity against human breast cancer cells with an $\mathrm{ED}_{50}$ of $2.2 \mu \mathrm{g} / \mathrm{ml}$ [35]. However, the antibacterial activity of the crude extract of $P$. nil seeds has yet to be reported. To the best of our knowledge, this is the first report of the antibacterial activity of the crude extract of $P$. nil seeds.

In this study, pharbitin was isolated as an antibacterial principle from $P$. nil seeds. It is an ether-insoluble resin glycoside, present as a mixture of various compounds. Two glycosidic acids, named pharbitic acids $C$ and D, along with valeric, tiglic, nilic, and (+)-2-methylbutyric acids, were isolated from the alkaline hydrolysis product of pharbitin [17, 30, 36]. In addition, Ono et al. [29] isolated seven acylated glycosidic acid methyl esters and proposed that pharbitin appears to be a mixture of seven monomers composed of free carboxylic acid forms (Fig. 2). In this study, we isolated one major compound from the alkaline product of the active fraction and it was identified as pharbitic acid C. This indicates that the active fraction obtained from $P$. nil seeds is pharbitin.

When the in vitro antibacterial activities of pharbitin and pharbitic acid $C$ were tested against various phytopathogenic bacteria, pharbitin was found to be active against Xanthomonas 
spp. and Rs. However, pharbitic acid C was not active, suggesting aglycone groups to be crucial to the antibacterial activity of pharbitin. Both the $\mathrm{BuOH}$ layer and pharbitin showed the same antibacterial spectrum against phytopathogenic bacteria; both samples were active only toward Xanthomonas spp. and Rs among the 14 phytopathogenic bacteria tested. This indicates that pharbitin is mainly responsible for the antibacterial activity of the $\mathrm{BuOH}$ layer.

Both the $\mathrm{BuOH}$ layer of $P$. nil seeds and isolated pharbitin controlled the development of bacterial leaf spot in a detached leaf bioassay using peach leaves, in a dosedependent manner. There are few studies on the biological control of bacteria spots on peach leaves. Kawaguchi et al. [1] reported the use of X. campestri strains AZ98101 and AZ98106 for controlling Xap in the field. Penicillic acid isolated from Aspergillus persii EML-HPB1-11 was shown to significantly decrease the development of bacterial leaf spot on peach leaf by $95.0 \%$ at a concentration of $333.3 \mu \mathrm{g} / \mathrm{ml}$ [9].

In this study, both the $\mathrm{BuOH}$ layer of $P$. nil seeds and pharbitin significantly reduced the development of tomato bacterial wilt caused by Rs. Although the in vitro antibacterial activity of pharbitin is four times weaker than that of streptomycin sulfate, the disease control efficacy of pharbitin is comparable to that of streptomycin sulfate; the control value of the former at $125 \mu \mathrm{g} / \mathrm{ml}$ was similar to that of the latter at $200 \mu \mathrm{g} / \mathrm{ml}, 7$ days after inoculation. At 14 days after inoculation, the control value of pharbitin at $250 \mu \mathrm{g} / \mathrm{ml}$ was similar to that of streptomycin sulfate at $200 \mu \mathrm{g} / \mathrm{ml}$. On the other hand, the disease control efficacies of the $\mathrm{BuOH}$ layer at 500, 1,000, and 2,000 $\mu \mathrm{g} / \mathrm{ml}$ were almost similar to those of pharbitin at 125,250 , and $500 \mu \mathrm{g} / \mathrm{ml}$. The in vivo antibacterial activities of the $\mathrm{BuOH}$ layer and pharbitin against Rs were almost identical to the in vitro antibacterial activities of the two samples. These results indicate that about $25 \%$ of the $\mathrm{BuOH}$ layer was pharbitin, and pharbitin is a major compound in the $\mathrm{BuOH}$ layer of $P$. nil seeds.

The use of plant products to control the development of tomato bacterial wilt caused by Rs under greenhouse conditions has been reported by research groups. Indian neem tree leaves have been successfully used for the control of tomato bacterial wilt in a greenhouse. Dry and fresh neem leaves displayed strong disease control efficacy for tomato bacterial wilt inhibition at a concentration of $60 \mathrm{~g}$ leaves/1 of soil with control values of $100 \%$ and $78 \%$, respectively, 30 days after incorporation in the soil [37]. Methyl gallate isolated from the methanol extract of Toxicodendron sylvestre significantly decreased the development of bacterial wilt on tomatoes by $78.6 \%$ at a concentration $1 \mathrm{~g} / 1$ at
26 days after inoculation [38]. Eight gallotannins isolated from Sedum takesimense effectively inhibited the growth of various plant pathogenic bacteria [6]. Furthermore, at a 200-fold dilution, the wettable powder-type formulation of the ethyl acetate layer of the aerial part of the plant also effectively suppressed the development of tomato bacterial wilt in plants by $78.3 \%, 14$ days after inoculation. Deberdt et al. [39] reported that the soil treatment of Allium fistulosum extract was effective in reducing tomato bacterial wilt. On the other hand, several plant essential oils, such as thymol, palmarosa, lemongrass, clove, and cinnamon oils, also significantly reduced the incidence of tomato bacterial wilt in greenhouse experiment [40-42]. Despite these interesting studies, to the best of our best knowledge, there is no commercially available botanical bacteriocide for the control of plant bacterial diseases.

In conclusion, pharbitin was isolated from $P$. nil seeds and determined to be the main antibacterial metabolite present. Both the $\mathrm{BuOH}$ layer and pharbitin showed specific antibacterial activity against Rs and Xanthomonas spp. They also reduced the development of bacterial leaf spot in a detached leaf assay using peach leaves, and tomato bacterial wilt in a pot experiment. These results suggest $P$. nil seed extract to be a promising candidate for the development of a new biopesticide for the control of plant diseases caused by Rs and Xanthomonas spp. However, further studies to develop an optimum extraction process and formulation, as well as to investigate the toxicity and determine the effective dose in field crops, are necessary before such a product can be commercialized.

\section{Acknowledgments}

This work was supported by the Korea Institute of Planning and Evaluation for Technology in Food, Agriculture, Forestry and Fisheries (IPET) through the Agri-Bio Industry Technology Development Program, funded by the Ministry of Agriculture, Food and Rural Affairs (MAFRA) (315007-3).

\section{Conflict of Interest}

The authors have no financial conflicts of interest to declare.

\section{References}

1. Kawaguchi A, Inoue K, Inoue Y. 2014. Biological control of bacterial spot on peach by nonpathogenic Xanthomonas campestris strains AZ98101 and AZ98106. J. Gen. Plant Pathol. 
80: $158-163$

2. Stefani E. 2010. Economic significance and control of bacterial spot/canker of stone fruits caused by Xanthomonas arboricola pv. pruni. J. Plant Pathol. 92: S1.99-S1.103.

3. Wallis FM, Truter SJ. 1978. Histopathology of tomato plants infected with Pseudomonas solanacearum with emphasis on ultrastructure. Physiol. Plant Pathol. 13: 307-310.

4. Genin S, Boucher C. 2004. Lessons learned from the genome analysis of Ralstonia solanacearum. Annu. Rev. Phytopathol. 42: 107-134.

5. Hayward AC. 1991. Biology and epidemiology of bacterial wilt caused by Pseudomonas solanacearum. Annu. Rev. Phytopathol. 29: 65-87.

6. Vu TT, Kim J-C, Choi YH, Choi GJ, Jang KS, Choi TH, et al. 2013. Effect of gallotannins derived from Sedum takesimense on tomato bacterial wilt. Plant Dis. 97: 1593-1598.

7. Yoon MY, Cha BG, Kim J-C. 2013. Recent trends in studies on botanical fungicides in agriculture. Plant Pathol. J. 29: 1-9.

8. Le Dang Q, Shin TS, Park MS, Choi YH, Choi GJ, Jang KS, et al. 2014. Antimicrobial activities of novel mannosyl lipids isolated from the biocontrol fungus Simplicillium lamellicola BCP against phytopathogenic bacteria. J. Agric. Food Chem. 62: 3363-3370.

9. Nguyen HT, Yu NH, Jeon SJ, Lee HW, Bae CH, Yeo JH, et al. 2016. Antibacterial activities of penicillic acid isolated from Aspergillus persii against various plant pathogenic bacteria. Lett. Appl. Microbiol. 62: 488-493.

10. Austin DF, Huáman Z. 1996. A synopsis of Ipomoea (Convolvulaceae) in the Americas. Taxon 29: 501-502.

11. Miller RE, Rausher MD, Manos PS. 1999. Phylogenetic systematics of Ipomoea (Convolvulaceae) based on ITS and waxy sequences. Syst. Bot. 24: 209-227.

12. Kim KH, Ha SK, Choi SU, Kim SY, Lee KR. 2011. Bioactive phenolic constituents from the seeds of Pharbitis nil. Chem. Pharm. Bull. 59: 1425-1429.

13. Corona-Castañeda B, Pereda-Miranda R. 2012. Morning glory resin glycosides as modulators of antibiotic activity in multidrug-resistant gram-negative bacteria. Planta Med. 78: 128-131.

14. Kawasaki T, Okabe H, Nakatsuka I. 1971. Studies on resin glycosides. I. Reinvestigation of the components of pharbitin, a resin glycoside of the seeds of Pharbitis nil Choisy. Chem. Pharm. Bull. 19: 2394-2403.

15. Kim KH, Choi SU, Lee KR. 2009. Diterpene glycosides from the seeds of Pharbitis nil. J. Nat. Prod. 72: 1121-1127.

16. Lee OS, Lee B, Park N, Koo JC, Kim YH, Prasad DT, et al. 2003. Pn-AMPs, the hevein-like proteins from Pharbitis nil confers disease resistance against phytopathogenic fungi in tomato, Lycopersicum esculentum. Phytochemistry 62: 1073-1079.

17. MacLeod JK, Ward A. 1997. Structural investigation of resin glycosides from Ipomoea lonchophylla. J. Nat. Prod. 60: 467-471.

18. Bensky D, Gamble A. 1993. Chinese Herbasl Medicine, Revised Ed. Materia Media, Eastland Press, Seattle.
19. Eich E. 2008. Solanaceae and Convolvulaceae: Secondary Metabolites, Springer Verlag, Berlin Heidelberg.

20. Okabe H, Kawasaki T. 1970. Structures of pharbitic acids C and D. Tetrahedron Lett. 36: 3123-3126.

21. Lee TH, Choi JJ, Kim DH, Choi S, Lee KR, Son M, et al. 2008. Gastroprokinetic effects of DA-9701, a new prokinetic agent formulated with Pharbitis Semen and Corydalis Tuber. Phytomedicine 15: 836-843.

22. Kim KH, Choi SU, Son MW, Lee KR. 2010. Two new phenolic amides from the seeds of Pharbitis nil. Chem. Pharm. Bull. 58: 1532-1535.

23. Koo JC, Lee SY, Chun HJ, Cheong YH, Choi JS, Kawabata S-I, et al. 1998. Two hevein homologs isolated from the seeds of Pharbitis nil L. exhibit potent antifungal activity. Biochim. Biophys. Acta 1382: 80-90.

24. Koo JC, Chun HJ, Park HC, Kim MC, Koo YD, Koo SC, et al. 2002. Over-expression of a seed specific hevein-like antimicrobial peptide from Pharbitis nil enhances resistance to a fungal pathogen in transgenic tobacco plants. Plant Mol. Biol. 50: 441-452.

25. Ko SG, Koh SH, Jun CY, Nam CG, Bae HS, Shin MK. 2004. Induction of apoptosis by Saussurea lappa and Pharbitis nil on AGS gastric cancer cells. Biol. Pharm. Bull. 27: 1604-1610.

26. Hao B, Liu GL, Hu XG, Wang GX. 2012. Bioassay-guided isolation and identification of active compounds from Semen pharbitidis against Dactylogyrus intermedius (Monogenea) in goldfish (Carassius auratus). Vet. Parasitol. 187: 452-458.

27. Lee HJ, Jo EJ, Kim NH, Chae Y, Lee S-W. 2011. Disease responses of tomato pure lines against Ralstonia solanacearum strains from Korea and susceptibility at high temperature. Res. Plant Dis. 17: 326-333.

28. Koh YJ, Kim GH, Jung JS, Lee YS, Hur JS. 2010. Outbreak of bacterial canker on Hort16A (Actinidia chinensis Planchon) caused by Pseudomonas syringae pv. actinidiae in Korea. N. Z. J. Crop Hort. Sci. 38: 275-282.

29. Ono M, Takigawa A, Mineno T, Yoshimitu H, Nohara $T$, Ikeda T, et al. 2010. Acylated glycosides of hydroxyl fatty acid methyl esters generated from the crude resin glycoside (pharbitin) of seeds of Pharbitis nil by treatment with indium(III) chloride in methanol. J. Nat. Prod. 73: 1846-1852.

30. Ono M, Noda N, Kawasaki T, Miyahara K. 1990. Resin glycosides. VII. Reinvestigation of the component organic and glycosidic acids of pharbitin, the crude ether-insoluble resin glycoside ("convolvulin") of Pharbitidis Semen (seeds of Pharbitis nil). Chem. Pharm. Bull. 38: 1892-1897.

31. Socquet-Juglard D, Patocchi A, Pothier JF, Christen D, Duffy B. 2012. Evaluation of Xanthomonas arboricola pv. pruni inoculation techniques to screen for bacterial spot resistance in peach and apricot. J. Plant Pathol. 94: S1.91-S1.96.

32. Winstead NN, Kelman A. 1952. Inoculation techniques for evaluating resistance to Pseudomonas solanacearum. Phytopathology 42: 628-634.

33. Bieber LW, da Silva Filho AA, Corrêa Lima RMO, de 
Andrade Chiappeta A, do Nascimento SC, de Souza IA, et al. 1986. Anticancer and antimicrobial glycosides from Ipomoea bahiensis. Phytochemistry 25: 1077-1081.

34. Reynolds WF, Yu M, Enriquez RG, Gonzalez H, Leon I, Magos G, et al. 1995. Isolation and characterization of cytotoxic and antibacterial tetrasaccharide glycosides from Ipomoea stans. J. Nat. Prod. 58: 1730-1734.

35. Pereda-Miranda R, Mata R, Anaya AL, Wickramaratne DBM, Pezzuto JM, Kinghorn AD. 1993. Tricolorin A, major phytogrowth inhibitor from Ipomoea tricolor. J. Nat. Prod. 56: 571-582.

36. Okabe H, Koshito N, Tanaka K, Kawasaki T. 1971. Studies on resin glycosides. II. Unhomogeneity of "pharbitic acid" and isolation and partial structures of pharbitic acids $C$ and D, the major constituents of "pharbitic acid". Chem. Pharm. Bull. 19: 2394-2403.

37. Pontes $\mathrm{N}$ de $\mathrm{C}$, Kronka AZ, Moraes MFH, Nascimento AS, Fujinawa MF. 2011. Incorporation of neem leaves into soil to control bacterial wilt of tomato. J. Plant Pathol. 93: 741-744.
38. Yuan G-Q, Li Q-Q, Qin J, Ye Y-F, Lin W. 2012. Isolation of methyl gallate from Toxicodendron sylvestre and its effect on tomato bacterial wilt. Plant Dis. 96: 1143-1147.

39. Deberdt P, Perrin B, Coranson-Beaudu R, Duyck P-F, Wicker E. 2012. Effect of Allium fistulosum extract on Ralstonia solanacearum populations and tomato bacterial wilt. Plant Dis. 96: 687-692.

40. Pradhanang PM, Momol MT, Olson SM, Jones JB. 2003. Effects of plant essential oils on Ralstonia solanacearum population density and bacterial wilt incidence in tomato. Plant Dis. 87: 423-427.

41. Ji P, Momol MT, Olson SM, Pradhanang PM, Jones JB. 2005. Evaluation of thymol as biofumigant for control of bacterial wilt of tomato under field conditions. Plant Dis. 89: 497-500.

42. Lee YH, Choi CW, Kim SH, Yun JG, Chang SW, Kim YS, et al. 2012. Chemical pesticides and plant essential oils for disease control of tomato bacterial wilt. Plant Pathol. J. 28: 32-39. 